\title{
Chilling-induced reduction of photosynthesis is mitigated by exposure to elevated $\mathrm{CO}_{2}$ concentrations
}

\author{
C. ARENA ${ }^{*}{ }^{+}$and L. VITALE ${ }^{* *}$ \\ Department of Biology, University of Naples Federico II, Via Cinthia, 80126, Naples, Italy* \\ Institute for Agricultural and Forestry Systems in the Mediterranean (ISAFoM), Department of Biology, Agriculture \\ and Food Sciences (DiSBA), National Research Council (CNR), Via Patacca 85, 80056, Ercolano (Italy) ${ }^{* *}$
}

\begin{abstract}
This work aimed to evaluate if chilling stress may be mitigated by elevated $\mathrm{CO}_{2}$ (EC) in Beta vulgaris L. plants. Photosynthetic rate was measured at $21 \%$ and $2 \% \mathrm{O}_{2}$ after a short-term exposure of $5 \mathrm{~h}$ at four different treatments: $360 \mu \mathrm{mol}\left(\mathrm{CO}_{2}\right) \mathrm{mol}^{-1} / 25^{\circ} \mathrm{C}(\mathrm{AC}) ; 360 \mu \mathrm{mol}\left(\mathrm{CO}_{2}\right) \mathrm{mol}^{-1} / 4^{\circ} \mathrm{C}(\mathrm{AC}+\mathrm{LT}) ; 700 \mu \mathrm{mol}\left(\mathrm{CO}_{2}\right) \mathrm{mol}^{-1} / 25^{\circ} \mathrm{C}(\mathrm{EC}) ; 700 \mu \mathrm{mol}\left(\mathrm{CO}_{2}\right)$ $\mathrm{mol}^{-1} / 4^{\circ} \mathrm{C}(\mathrm{EC}+\mathrm{LT})$. Compared to $\mathrm{AC}+\mathrm{LT}, \mathrm{EC}+\mathrm{LT}$ plants showed higher values of $\mathrm{CO}_{2}$ fixation, photochemical activity, and Rubisco amount. These latter invest a higher portion of photosynthetic electron flow to $\mathrm{O}_{2}$, differently from AC+LT plants that promote the regulated thermal dissipation processes. In EC+LT plants, the photosynthetic electron flow to $\mathrm{O}_{2}$ acts as a safety mechanism against the excess of absorbed light, upon return to prechilling conditions, allowing photosynthetic apparatus to maintain its efficiency. In AC+LT plants, the increase of thermal dissipation processes was not adequate to guarantee the PSII photoprotection and the photosynthetic recovery after chilling.
\end{abstract}

Additional key words: chilling; elevated $\mathrm{CO}_{2}$; partitioning of absorbed light to PSII; photosynthetic rate.

\section{Introduction}

Chilling represents a critical environmental stress that limits plant productivity and distribution in many regions of the world. In response to this constraint, plants have developed an elaborate defence system, namely cold acclimation, that confers chilling/freezing tolerance (Huner et al. 1993, Zheng et al. 2014). The acclimation to cold consists in reversible molecular, biochemical, and physiological modifications primed by the exposure to low temperatures in some periods of the day or season. From the ecological point of view, these changes are significant because allow many species to adapt successfully to own dynamic environment, maintaining the photosynthetic rate $\left(P_{\mathrm{N}}\right)$ over winter (Janská et al. 2010).

The reduction of photosynthesis induced by chilling is a typical response of both chilling-sensitive and chillingtolerant plants (Martin et al. 1981, Venema et al. 2000). Such decrease might be observed not only during but also after chilling period because of the slow recovery of $P_{\mathrm{N}}$ due to both stomatal and nonstomatal limitations (Melkonian et al. 2004). A small drop in temperature, even if it does not produce visible damage may induce up to $50 \%$ reduction of plant productivity, because of chilling acts on important physiological processes, such as water uptake, mineral nutrition, photosynthesis, respiration, and total metabolism. The photosynthesis depression may be ascribed to different physiological constraints, such as stomatal and nonstomatal limitations to gas diffusion into the leaf, and biochemical constraints. More specifically, low temperatures inhibit photosynthesis either directly impairing PSII (Govindachary et al. 2004, Huang et al. 2010) and indirectly affecting Calvin-cycle enzymes (Venema et al. 1999, Allen and Ort 2001). The decline of photosynthesis at chilling temperatures may also be a consequence of photoinhibition and photooxidative damages

Received 4 August 2017, accepted 3 January 2018, published as online-first 21 June 2018.

${ }^{+}$Corresponding author; phone: +39081679173 , fax: +39081679233 , e-mail: c.arena@unina.it

Abbreviations: $\mathrm{AC}$ - ambient $\left[\mathrm{CO}_{2}\right] ;\left[\mathrm{CO}_{2}\right]-\mathrm{CO}_{2}$ concentration; Chl - chlorophyll; $C_{\mathrm{i}}$ - intercellular $\mathrm{CO}_{2}$ concentration; EC - elevated $\left[\mathrm{CO}_{2}\right] ; \mathrm{F}_{0}$ - minimal fluorescence yield of the dark-adapted state; $\mathrm{F}_{0}{ }^{\prime}$ - minimal fluorescence yield of the light-adapted state; $\mathrm{F}_{\mathrm{m}}-$ maximal fluorescent yield of the dark-adapted state; $\mathrm{F}_{\mathrm{m}}{ }^{\prime}$ - maximal fluorescence level in light-adapted state; $\mathrm{F}_{\mathrm{v}}-$ variable fluorescence; $\mathrm{F}_{\mathrm{v}} / \mathrm{F}_{\mathrm{m}}$ - maximum quantum yield of PSII photochemistry; $\mathrm{F}_{\mathrm{s}}$ - steady-state fluorescence yield; $g_{\mathrm{s}}$ - stomatal conductance; $\mathrm{J}_{\mathrm{f}}-$ electron transport rate; $\mathrm{J}_{\mathrm{c}}$ - electron transport rate used for $\mathrm{CO}_{2}$ assimilation; $\mathrm{J}_{\mathrm{o}}$ - electron transport rate used for photorespiration; $\mathrm{K}-\mathrm{Kelvin}$; LT - low temperature; $P_{\mathrm{N}}$ - net photosynthetic rate; $R_{\mathrm{D}}$ - dark respiration; TCA - trichloroacetic acid; $\mathrm{V}_{\mathrm{c}}-$ carboxylation rate of Rubisco; $\mathrm{V}_{\mathrm{o}}$ - oxygenation rate of Rubisco; $\Phi_{\mathrm{PSI}}$ - effective quantum yield of PSII photochemistry; $\Phi_{\mathrm{NPQ}}$ - the yield of regulated energy dissipation; $\Phi_{\mathrm{NO}}$ - the yield of nonregulated energy dissipation. 
to the photosystems. In such circumstances, the balance between energy absorption and utilization is modified and detrimental effects are evident by increased lipid peroxidation, degradation of chlorophylls ( $\mathrm{Chl})$, carotenoids, and xanthophylls and reduced antioxidant capability (Fryer et al. 1998, Leipner et al. 2000, Alam and Jacob 2002).

Such situation can also continue after the chilling event as consequence of a delayed recovery of photosynthesis further enhancing the susceptibility of photosynthetic apparatus to photodamages.

Chilling-tolerant species show a reduction in photosynthesis during a chilling episode, but unlike chillingsensitive species, recover more or less instantaneously with the return to permissive temperatures.

Most crop species have evolved a degree of cold tolerance, depending on the combination of the minimum temperature experienced and the length of exposure to cold (Janská et al. 2010).

Against cold, plants have developed two main strategies: invest more light energy in photochemical processes by increasing photosynthetic capacity or promote the nonphotochemical mechanisms that safely dissipate the excess of excitation energy as heat (Huner et al. 1993, Rapacz et al. 2008).

It is well known that plants exposed to short-term $\mathrm{CO}_{2}$ enrichment increase photosynthetic capacity depending on plant species, developmental stage, and environmental conditions (Ainsworth and Rogers 2007, Duarte et al. 2014). Nevertheless, with long-term exposure to elevated $\mathrm{CO}_{2}$, photosynthetic acclimation or the down-regulation of photosynthesis may occur, offsetting such stimulation

\section{Materials and methods}

Plant material and growth conditions: The experiment was carried out during 2016 at the Department of Biology (University of Naples Federico II, Italy). Seeds of Beta vulgaris L. cv. Cicla were sown in $4-\mathrm{L}$ pots filled with a 1:1 (v/v) mixture of peat and soil. Germinated seeds were transferred to plant growth chamber at the following conditions: $25^{\circ} \mathrm{C}$, air relative humidity of $65 \%, 200$ $\mu \mathrm{mol}$ (photon) $\mathrm{m}^{-2} \mathrm{~s}^{-1}$ PAR at the top of the canopy, and a photoperiod of $12 \mathrm{~h}$. Irradiation was provided by a series of 28-W fluorescent tubes (Nurdex T5-6500 K). Plants were irrigated twice every week and fertilised once a week with a commercial nutritional solution (Cifo, Italy; N:P:K 20:20:20 + micronutrients). For the experiments, two different plant groups were used.
(Moore et al. 1999, Urban et al. 2012, Sanz-Sáez et al. 2013).

Many studies have been performed to investigate the combined effects of elevated $\mathrm{CO}_{2} /$ high temperature (Hamilton et al. 2008, Gutiérrez et al. 2009, Qu et al. 2014) or high $\mathrm{CO}_{2}$ /low temperatures (Boese et al. 1997, Ziska 2001, Laing et al. 2002) on photosynthetic performance. Some studies show a lower chilling/freezing tolerance of photosynthetic apparatus in plants exposed to elevated $\mathrm{CO}_{2}$ (Loveys et al. 2006, Bertrand et al. 2007, Martin et al. 2010), due to the higher leaf temperature as consequence of a reduced stomatal conductance $\left(g_{\mathrm{s}}\right)$. Other experiments report an improved resistance of photosynthetic machinery to low temperatures under elevated $\mathrm{CO}_{2}$. This response has been ascribed to an increase in electron transport to carbon fixation (Ziska 2001, Laing et al. 2002, Dahal et al. 2014) or to a reduced $g_{\text {s }}$ that limits chilling-induced water stress and photosynthetic depression (Boese et al. 1997, Drake et al. 1997). The cold tolerance mechanisms can also be modified by photosynthetic acclimation occurring both upon short- and longterm exposure to rising atmospheric $\mathrm{CO}_{2}$ concentrations (Bigras and Bertrand 2006).

This work aimed to study the role of elevated $\mathrm{CO}_{2}$ concentrations in mitigating chilling-induced photosynthetic depression in Beta vulgaris L., a winter crop widely cultivated in the Mediterranean agro-ecosystems. In particular, we investigated whether and how elevated $\mathrm{CO}_{2}$ concentrations may affect plant response to chilling inducing a different regulation of leaf gas exchanges and PSII light energy partitioning.

Experimental design: All plant groups were exposed for $5 \mathrm{~h}$ to four different temperature and $\mathrm{CO}_{2}$ treatments at the irradiance of $200 \mu$ mol(photon) $\mathrm{m}^{-2} \mathrm{~s}^{-1}$ in a growth chamber equipped with LED lighting system. The lighting consisted of thirteen different wavelengths from ultraviolet $(370 \mathrm{~nm})$ to infrared $(940 \mathrm{~nm})$ and two types of phosphorcoated LEDs for white light $(5000 \mathrm{~K}-6500 \mathrm{~K})$. The $\mathrm{CO}_{2}$ treatments inside the chamber were obtained flowing air at different $\mathrm{CO}_{2}$ concentrations from gas bottles at specific $\left[\mathrm{CO}_{2}\right]$. The $\mathrm{CO}_{2}$ concentration in the chamber was monitored using a $\mathrm{CO}_{2}$ analyser (Qubit Systems, Kingston, Canada). The performed treatments were:

\begin{tabular}{llll}
\hline $\begin{array}{l}\mathrm{CO}_{2} \text { concentration } \\
{\left[\mu \mathrm{mol}\left(\mathrm{CO}_{2}\right) \mathrm{mol}^{-1}\right]}\end{array}$ & $\begin{array}{l}\text { Temperature } \\
{\left[{ }^{\circ} \mathrm{C}\right]}\end{array}$ & Treatment & Assignment \\
\hline 360 & 25 & - & $\mathrm{AC}$ \\
360 & 4 & low temperature & $\mathrm{AC}+\mathrm{LT}$ \\
700 & 25 & elevated $\mathrm{CO}_{2}$ & $\mathrm{EC}$ \\
700 & 4 & elevated $\mathrm{CO}_{2}$ and low temperature & EC+LT \\
\hline
\end{tabular}


In the first group of plant, after each treatment, $P_{\mathrm{N}}$-PPFD curves were performed at $25^{\circ} \mathrm{C}$ and ambient $\left[\mathrm{CO}_{2}\right]$ to assess the value of saturation irradiance for photosynthesis.

On the second group of plants, before each treatment, the maximal quantum yield of PSII photochemistry $\left(\mathrm{F}_{\mathrm{v}} / \mathrm{F}_{\mathrm{m}}\right)$ and the dark respiration $\left(R_{\mathrm{D}}\right)$ were determined on 30 -min dark-adapted leaves. After the exposure for $5 \mathrm{~h}$ to different treatments, $\mathrm{F}_{\mathrm{v}} / \mathrm{F}_{\mathrm{m}}$ ad $R_{\mathrm{D}}$ were measured again on $30-\mathrm{min}$ dark-adapted leaves. Measurements of gas exchanges and Chl fluorescence emission in the light were carried out at $25^{\circ} \mathrm{C}$ and sub-saturating light intensity for photosynthesis [PAR of $200 \mu \mathrm{mol}$ (photon) $\mathrm{m}^{-2} \mathrm{~s}^{-1}$ ] under photorespiratory $\left(21 \% \quad \mathrm{O}_{2}\right.$ and $\left.0.036 \% \quad \mathrm{CO}_{2}\right)$ and nonphotorespiratory $\left(2 \% \mathrm{O}_{2}\right.$ and $\left.0.036 \% \mathrm{CO}_{2}\right)$ conditions. After each treatment, plants were darkened for $14 \mathrm{~h}$ and $\mathrm{F}_{\mathrm{v}} / \mathrm{F}_{\mathrm{m}}$ ad $R_{\mathrm{D}}$ measured again to assess the recovery from chilling event.

Gas exchange and $\mathrm{Chl}$ fluorescence measurements were performed simultaneously on 30-d-old fully expanded leaves, under photorespiratory and nonphotorespiratory conditions at ambient $\left[\mathrm{CO}_{2}\right]$ of $360 \mu \mathrm{mol}\left(\mathrm{CO}_{2}\right) \mathrm{mol}^{-1}$ using a portable photosynthesis and fluorescence system (Li6400 combined with a Li6400-40 leaf chamber fluorometer, Licor, USA). Gas-exchange parameters (i.e. net photosynthetic rate, $P_{\mathrm{N}}$; stomatal conductance to $\mathrm{H}_{2} \mathrm{O}, g_{\mathrm{s}}$; intercellular $\left[\mathrm{CO}_{2}\right], C_{\mathrm{i}}$ ) were calculated according to von Caemmerer and Farquhar (1981) by the software operating in Li6400. The apparent carboxylation efficiency $\left(P_{\mathrm{N}} / C_{\mathrm{i}}\right)$ was used as an indicator to evaluate the occurrence of stomatal and nonstomatal limitations.

On dark-adapted leaves, minimal fluorescence yield of the dark-adapted state, $\mathrm{F}_{0}$, was induced by weak modulated measuring beam of $0.03 \mu$ mol(photon) $\mathrm{m}^{-2} \mathrm{~s}^{-1}$. The maximal fluorescence yield of the dark-adapted state, $F_{m}$, was measured by an $800-\mathrm{ms}$ saturating light pulse of $8,000 \mu \mathrm{mol}$ (photon) $\mathrm{m}^{-2} \mathrm{~s}^{-1}$; the maximal quantum yield of PSII photochemistry $\left(\mathrm{F}_{\mathrm{v}} / \mathrm{F}_{\mathrm{m}}\right)$ was calculated as $\left(\mathrm{F}_{\mathrm{m}}-\mathrm{F}_{0}\right) / \mathrm{F}_{\mathrm{m}}$. The steady-state fluorescence yield, $F_{s}$, was measured upon illumination. The maximal fluorescence yield of the light-adapted state, $\mathrm{F}_{\mathrm{m}}$, was measured by applying an 800 $\mathrm{ms}$ saturating flash of $8,000 \mu \mathrm{mol}$ (photon) $\mathrm{m}^{-2} \mathrm{~s}^{-1}$; the minimal fluorescence yield of the light-adapted state, $\mathrm{F}_{0}$, was obtained turning off the actinic light and applying a far-red pulse.

The partitioning of absorbed light energy within PSII was calculated following the model of Kramer et al. (2004). The effective quantum yield of PSII photochemistry $\left(\Phi_{\mathrm{PSII}}\right)$ was estimated following Genty et al. (1989) as: $\Phi_{\text {PSII }}=\left(\mathrm{F}_{\mathrm{m}}{ }^{\prime}-\mathrm{F}_{\mathrm{s}}\right) \mathrm{F}_{\mathrm{m}}$. The yield of regulated energy dissipation was calculated as: $\Phi_{\mathrm{NPQ}}=1-\Phi_{\mathrm{PSII}}-1 /$ $\left[\mathrm{NPQ}+1+\mathrm{q}_{\mathrm{L}}\left(\mathrm{F}_{\mathrm{m}} / \mathrm{F}_{0}-1\right)\right]$, the yield of nonregulated energy dissipation was estimated as: $\Phi_{\mathrm{NO}}=1 /[\mathrm{NPQ}+1+$ $\left.\mathrm{q}_{\mathrm{L}} \times\left(\mathrm{F}_{\mathrm{m}} / \mathrm{F}_{0}-1\right)\right]$. The nonphotochemical quenching, NPQ, was expressed according to Bilger and Björkman (1990). The PSII "excitation pressure" or the relative reduction state of PSII was calculated as $1-\mathrm{q}_{\mathrm{L}}$, where $\mathrm{q}_{\mathrm{L}}$ represents the photochemical quenching (Kramer et al. 2004).

The electron transport rate measured by chlorophyll fluorescence $\left(J_{\mathrm{f}}\right)$ was calculated following Krall and Edwards (1992) as: $\Phi_{\text {PSII }} \times$ PPFD $\times 0.5 \times 0.84$, where 0.5 is a factor implicating an equal distribution of energy between photosystems (Krall and Edwards 1992) and 0.84 the assumed leaf absorbance for B. vulgaris. Lightresponse curves under nonphotorespiratory conditions $\left(\begin{array}{ll}2 \% & \mathrm{O}_{2}\end{array}\right)$ were performed to calibrate the relationship between fluorescence-derived electron transport rates and photosynthesis.

In this study, we used $J_{\mathrm{f}} / P_{\mathrm{N}}$ ratio as an indicator of electron transport to acceptors other than $\mathrm{CO}_{2}$, as previously reported by other authors (Krall and Edwards 1992, Flexas et al. 1998, Medrano et al. 2002). According to Epron et al. (1995), $J_{\mathrm{f}}$ was divided into two components: $J_{\mathrm{f}}=J_{\mathrm{c}}+J_{\mathrm{o}}$.

$J_{\mathrm{c}}$ is the fraction of $J_{\mathrm{f}}$ used for $\mathrm{CO}_{2}$ assimilation $\left(J_{\mathrm{c}}=1 / 3\left[J_{\mathrm{f}}+8\left(P_{\mathrm{N}}+R_{\mathrm{L}}\right)\right]\right)$ and $J_{\mathrm{o}}$ is the fraction of $J_{\mathrm{f}}$ used for photorespiration $\left(J_{\mathrm{o}}=2 / 3\left[J_{\mathrm{f}}-4\left(P_{\mathrm{N}}+R_{\mathrm{L}}\right)\right]\right)$. This approach assumes that all the reducing power generated by the electron transport chain is used for photosynthesis and photorespiration, and Chl fluorescence gives a reliable estimation of the quantum yield of electron transport. $P_{\mathrm{N}}-\mathrm{PPFD}$ curves performed at $2 \% \mathrm{O}_{2}$ showed that $J_{\mathrm{f}} / P_{\mathrm{N}}$ ratio was 4-5 in the all utilized light range (data not shown), in agreement with the theoretical value (Krall and Edwards 1992). Based on this assumption, the processes consuming reductive power other than photosynthesis and photorespiration are negligible in $B$. vulgaris grown under our experimental conditions.

The rates of carboxylation $\left(V_{\mathrm{c}}\right)$ and oxygenation $\left(V_{\mathrm{o}}\right)$ of Rubisco were calculated as: $V_{\mathrm{c}}=1 / 6\left[J_{\mathrm{f}} / 2+4\left(P_{\mathrm{N}}+R_{\mathrm{L}}\right)\right]$ and $V_{\mathrm{o}}=1 / 6\left[J_{\mathrm{f}}-4\left(P_{\mathrm{N}}+R_{\mathrm{L}}\right)\right]$, respectively (von Caemmerer 2000). Day respiration, $R_{\mathrm{L}}$ for calculation of $J_{\mathrm{fc}}, J_{\mathrm{fo}}, V_{\mathrm{c}}$, and $V_{\mathrm{o}}$ was assumed to be half of $R_{\mathrm{D}}$ (von Caemmerer 2000).

Rubisco expression: Leaf protein extraction was carried out following the procedure reported in Arena et al. (2017). Leaf tissues ( $1 \mathrm{~g})$, were ground in a mortar under liquid nitrogen. The powder was suspended in solution $10 \% \mathrm{TCA} /$ acetone, centrifuged at $16,000 \times \mathrm{g}$ for $3 \mathrm{~min}$ at $4^{\circ} \mathrm{C}$ and then washed first with methanol $(80 \%)$ and after in acetone $(80 \%)$. After drying $\left(50^{\circ} \mathrm{C}\right.$ for $\left.10 \mathrm{~min}\right)$, the pellet was re-suspended in 1:1 phenol ( $\mathrm{pH} 8.0) / \mathrm{SDS}(\mathrm{v}: \mathrm{v})$ buffer and centrifuged at $16,000 \times g$ for $3 \mathrm{~min}$. The upper phenol phase was treated with methanol containing $0.1 \mathrm{M}$ ammonium acetate, stored overnight at $20^{\circ} \mathrm{C}$ and centrifuged again. The pellet was washed once with $100 \%$ methanol and once with $80 \%$ acetone and after resuspended in an SDS sample buffer. The protein quantification was carried out by Quick Start ${ }^{T M}$ Bradford protein assay (Bio-Rad Laboratories S.r.l., Segrate, Milano, Italy).

For Western blotting analysis, $5 \mu \mathrm{g}$ of proteins from the cytoplasmic fraction together with RbcL protein standard $(2 \mu \mathrm{g})$ were analysed on $12 \%$ polyacrylamide slab gels in 
the presence of $0.1 \%$ sodium dodecyl sulphate (SDS) and electrotransferred onto $0.2 \mu \mathrm{m}$ pore-size nitrocellulose membrane (Bio-Rad Laboratories S.r.l., Segrate, Milano, Italy) at $100 \mathrm{~V}$ for $4 \mathrm{~h}$ at $4^{\circ} \mathrm{C}$ in the transfer buffer (Trisglycine, methanol, $\mathrm{H}_{2} \mathrm{O}$ ). The nitrocellulose membrane was treated for $1 \mathrm{~h}$ with blocking solution $(50 \mathrm{mM}$ Tris$\mathrm{HCl}, \mathrm{pH} 8.0,150 \mathrm{mM} \mathrm{NaCl}, 0.5 \%$ (v/v) Tween 20, TBST) and $5 \%(\mathrm{w} / \mathrm{v})$ dry milk. The incubation with commercial rabbit anti RbcL (type $1+$ type 2) antibody (Agrisera, $1: 10,000, \mathrm{v} / \mathrm{v}$ ) was performed for $1 \mathrm{~h}$ at room temperature in the same solution supplemented with $5 \%(\mathrm{w} / \mathrm{v})$ dry milk. The blot was then washed several times with buffer TBST and antibody binding detected using horseradish peroxidase (HRP)-conjugated goat anti-rabbit secondary antibody (Pierce; 1:5,000; v/v). HRP reaction used a kit for chemiluminescence (Westar Supernova, Cyanagen S.r.l., Bologna, Italy) and Chemidoc apparatus (Bio-Rad). Actin was used as loading control. Each Rubisco band was normalized to the appropriate actin band. Density values

\section{Results}

Recovery from treatments: $F_{v} / F_{m}$ ratio, measured on 30-min dark-adapted leaves after returning to prechilling conditions, decreases by $18 \%$ in $\mathrm{AC}+\mathrm{LT}$ plants and $7 \%$ EC+LT plants (Table 1). Both plant groups also showed the higher $\mathrm{F}_{0}$ and the lower $\mathrm{F}_{\mathrm{m}}$ values compared to the initial value (Table 1 ). After $14 \mathrm{~h}$ of darkness, $\mathrm{F}_{\mathrm{v}} / \mathrm{F}_{\mathrm{m}}$ ratio returned to the initial values in both $\mathrm{AC}+\mathrm{LT}$ and $\mathrm{EC}+\mathrm{LT}$ plant groups (Table 1).

$\boldsymbol{P}_{\mathbf{N}}-$ PPFD curves: In all treatments, the light saturation point for photosynthesis was $800 \mu \operatorname{mol}\left(\right.$ photon) $\mathrm{m}^{-2} \mathrm{~s}^{-1}$ PAR (Fig. 1). The highest $P_{\mathrm{N}}$ values were measured in EC plants, whereas the lowest values in AC+LT plants. $P_{\mathrm{N}}$ in $\mathrm{AC}$ and $\mathrm{EC}+\mathrm{LT}$ exhibited intermediate values, being in $\mathrm{EC}+\mathrm{LT}$ significantly higher than that in $\mathrm{AC}+\mathrm{LT}$ plants (Fig. 1).

Gas exchanges and $\mathrm{Chl}$ fluorescence measurements: Net photosynthetic rate $\left(P_{\mathrm{N}}\right)$ measured at $21 \% \mathrm{O}_{2}$ was are expressed in arbitrary units and represented as bar diagrams that are pixel volumes of Rubisco bands. The data are processed with Quantity One 1-D Analysis software (Bio-Rad), after minimising background effect.

Statistical analysis: Statistical significant differences among treatments were analysed by two-way analysis of variance $(A N O V A)$ using $\mathrm{CO}_{2}$ and temperature as independent factors, to assess the interaction between $\mathrm{CO}_{2}$ and temperature. Shapiro-Wilk and Kolmogorov-Smirnov tests were performed to check for normality. The HolmSidak test was applied for all multiple comparison procedures based on a significance level of $p<0.05$. Differences between photorespiratory and nonphotorespiratory conditions were assessed by $t$-test based on a significance level of $p<0.05$. The package Sigma-Plot 12.0 (Jandel Scientific, San Rafael, CA, USA) was used for graphical and statistical data processing.

significantly lower than that measured at $2 \% \mathrm{O}_{2}$ in all treatments (Fig. $2 A$ ).

The exposure to low temperatures determined a significant reduction of $P_{\mathrm{N}}$ in $\mathrm{AC}+\mathrm{LT}$ and $\mathrm{EC}+\mathrm{LT}$ plants at both $\mathrm{O}_{2}$ concentrations. The chilling-induced reduction of $P_{\mathrm{N}}$ was higher in $\mathrm{AC}+\mathrm{LT}$ than that in $\mathrm{EC}+\mathrm{LT}$ plants (Fig. 2A).

Stomatal conductance to $\mathrm{CO}_{2}\left(g_{\mathrm{s}}\right)($ Fig. $2 B)$ and $P_{\mathrm{N}} / C_{\mathrm{i}}$ ratio (Fig. 2C) showed a similar trend of $P_{\mathrm{N}}$ : these parameters decreased in $\mathrm{AC}+\mathrm{LT}$ and $\mathrm{EC}+\mathrm{LT}$ compared to $\mathrm{AC}$ and $\mathrm{EC}$ plants at both $\mathrm{O}_{2}$ concentrations. The reduction was higher in $\mathrm{AC}+\mathrm{LT}$ than that in $\mathrm{EC}+\mathrm{LT}$ plants.

The carboxylation rate $\left(V_{\mathrm{c}}\right)$, measured at 21 and $2 \% \mathrm{O}_{2}$, significantly decreased in $\mathrm{AC}+\mathrm{LT}$ and $\mathrm{EC}+\mathrm{LT}$ plants compared with control (Fig. $2 D$ ); the lowest value was measured in $\mathrm{AC}+\mathrm{LT}$ plants. The oxygenation rate $\left(V_{\mathrm{o}}\right)$ at $21 \% \mathrm{O}_{2}$ decreased in AC+LT compared to other plant groups. The highest value was measured in $\mathrm{EC}+\mathrm{LT}$ plants (Fig. 2D).

Table 1. Recovery of $\mathrm{F}_{0}, \mathrm{~F}_{\mathrm{m}}$, and $\mathrm{F}_{\mathrm{v}} / \mathrm{F}_{\mathrm{m}}$, in B. vulgaris leaves after a dark period of 30 min and $14 \mathrm{~h}$ from different treatments. AC ambient $\left[\mathrm{CO}_{2}\right] ; \mathrm{AC}+\mathrm{LT}-$ ambient $\left[\mathrm{CO}_{2}\right]$ and low temperature; $\mathrm{EC}$ - elevated $\left[\mathrm{CO}_{2}\right] ; \mathrm{EC}+\mathrm{LT}-$ elevated $\mathrm{CO}_{2}$ and low temperature. Values are means $\pm \mathrm{SE}(n=6)$. Different letters indicate statistically significant differences among treatments at $21 \% \mathrm{O}_{2}$.

\begin{tabular}{|c|c|c|c|c|c|c|c|}
\hline & & $\mathrm{AC}+\mathrm{LT}$ & & $\mathrm{EC}$ & & $\mathrm{EC}+\mathrm{LT}$ & \\
\hline & Initial value & $30 \min$ & $14 \mathrm{~h}$ & $30 \mathrm{~min}$ & $14 \mathrm{~h}$ & $30 \mathrm{~min}$ & $14 \mathrm{~h}$ \\
\hline $\mathrm{F}_{0}$ & $0.224 \pm 0.002^{\mathrm{a}}$ & $0.297 \pm 0.008^{\mathrm{b}}$ & $0.219 \pm 0.008^{\mathrm{a}}$ & $0.219 \pm 0.003^{\mathrm{a}}$ & $0.229 \pm 0.008^{\mathrm{a}}$ & $0.267 \pm 0.002^{\mathrm{c}}$ & $0.216 \pm 0.002^{\mathrm{a}}$ \\
\hline $\mathrm{F}_{\mathrm{m}}$ & $1.292 \pm 37.642^{\mathrm{a}}$ & $0.926 \pm 0.003^{b}$ & $1.180 \pm 37.964^{\mathrm{a}}$ & $1.167 \pm 18.023^{\mathrm{a}}$ & $1.213 \pm 44.681^{\mathrm{a}}$ & $1.065 \pm 24.973^{\mathrm{c}}$ & $1.188 \pm 24.024$ \\
\hline $\mathrm{F}_{\mathrm{v}} / \mathrm{F}_{\mathrm{m}}$ & $0.826 \pm 0.006^{\mathrm{a}}$ & $0.679 \pm 0.007^{b}$ & $0.814 \pm 0.003^{\mathrm{a}}$ & $0.812 \pm 0.005^{\mathrm{a}}$ & $0.811 \pm 0.003^{\mathrm{a}}$ & $0.749 \pm 0.004^{\mathrm{c}}$ & $0.818 \pm 0.003^{\mathrm{a}}$ \\
\hline
\end{tabular}

Compared with control, the fraction of electron transport used for $\mathrm{CO}_{2}$ assimilation, $J_{\mathrm{c}}$, decreased in both $\mathrm{AC}+\mathrm{LT}$ and $\mathrm{EC}+\mathrm{LT}$ plants under photorespiratory and nonphotorespiratory conditions. This decrease was $42 \%$ in $\mathrm{AC}+\mathrm{LT}$ and $17 \%$ in $\mathrm{EC}+\mathrm{LT}$ plants; conversely, no difference between control and EC plants was found (Fig. 3A). The fraction of electron transport used for photorespiration, $J_{\mathrm{o}}$, showed the lowest value in AC+LT and the highest value in EC+LT plants (Fig. $3 A$ ). The $J_{\mathrm{f}} / P_{\mathrm{N}}$ ratio measured at $21 \% \mathrm{O}_{2}$ did not show any differences 


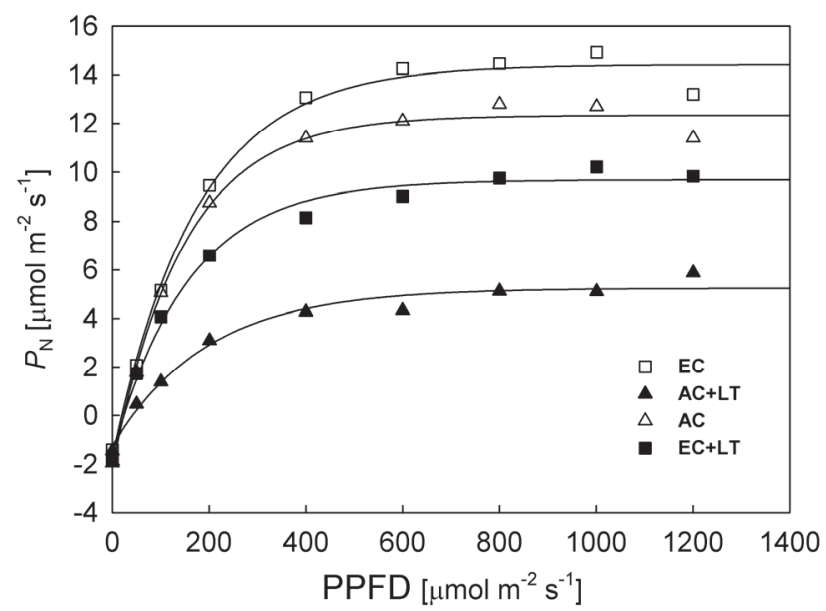

Fig. 1. $P_{\mathrm{N}}-\mathrm{PPFD}$ curves performed at $25^{\circ} \mathrm{C}$ and ambient $\left[\mathrm{CO}_{2}\right]$ on Beta vulgaris plants after 5-h exposure at each treatment. Values are means $\pm \mathrm{SE}(n=6)$. $\mathrm{AC}-$ ambient $\left[\mathrm{CO}_{2}\right] ; \mathrm{AC}+\mathrm{LT}-$ ambient $\left[\mathrm{CO}_{2}\right]$ and low temperature; EC - elevated $\left[\mathrm{CO}_{2}\right]$; $\mathrm{EC}+\mathrm{LT}-$ elevated $\left[\mathrm{CO}_{2}\right]$ and low temperature.

\section{Discussion}

Gas exchanges in response to different treatments: Changes of temperature modify the balance of energy absorbed during the light phase of photosynthesis and the energy utilized in dark processes. The reduction of photosynthesis induced by cold may continue after chilling period because of the occurrence of persistent stomatal and between treatments, except for EC+LT plants, where an increase of $20 \%$ compared with control was found (Fig. $3 B$ ). At $2 \% \mathrm{O}_{2}$, the $J_{\mathrm{f}} / P_{\mathrm{N}}$ ratio did not vary among treatments and was near to the theoretical value (4-5).

The partitioning of absorbed light energy within PSII, measured at $21 \% \mathrm{O}_{2}$, showed in $\mathrm{AC}+\mathrm{LT}$ plants the lowest $\Phi_{\mathrm{PSII}}$ and the highest $\Phi_{\mathrm{NPQ}}$ and $\Phi_{\mathrm{NO}}$ values compared to other plant groups. $\mathrm{AC}+\mathrm{LT}$ and $\mathrm{EC}+\mathrm{LT}$ plants exhibited comparable values of $\Phi_{\mathrm{NO}}$ (Fig. $3 C$ ).

Rubisco expression and content: The Rubisco protein expression was differently modulated in the different treatments (Fig. 4A); in particular, $\mathrm{AC}+\mathrm{LT}$ treatment caused in leaves a significant decrease of Rubisco content compared with control and EC treatments. In particular, the EC treatment stimulated the Rubisco expression compared with control. The combination of elevated $\mathrm{CO}_{2}$ and low temperature $(\mathrm{EC}+\mathrm{LT})$, mitigated the reduction of Rubisco contents compared with $\mathrm{AC}+\mathrm{LT}$ treatment (Fig. 4B).

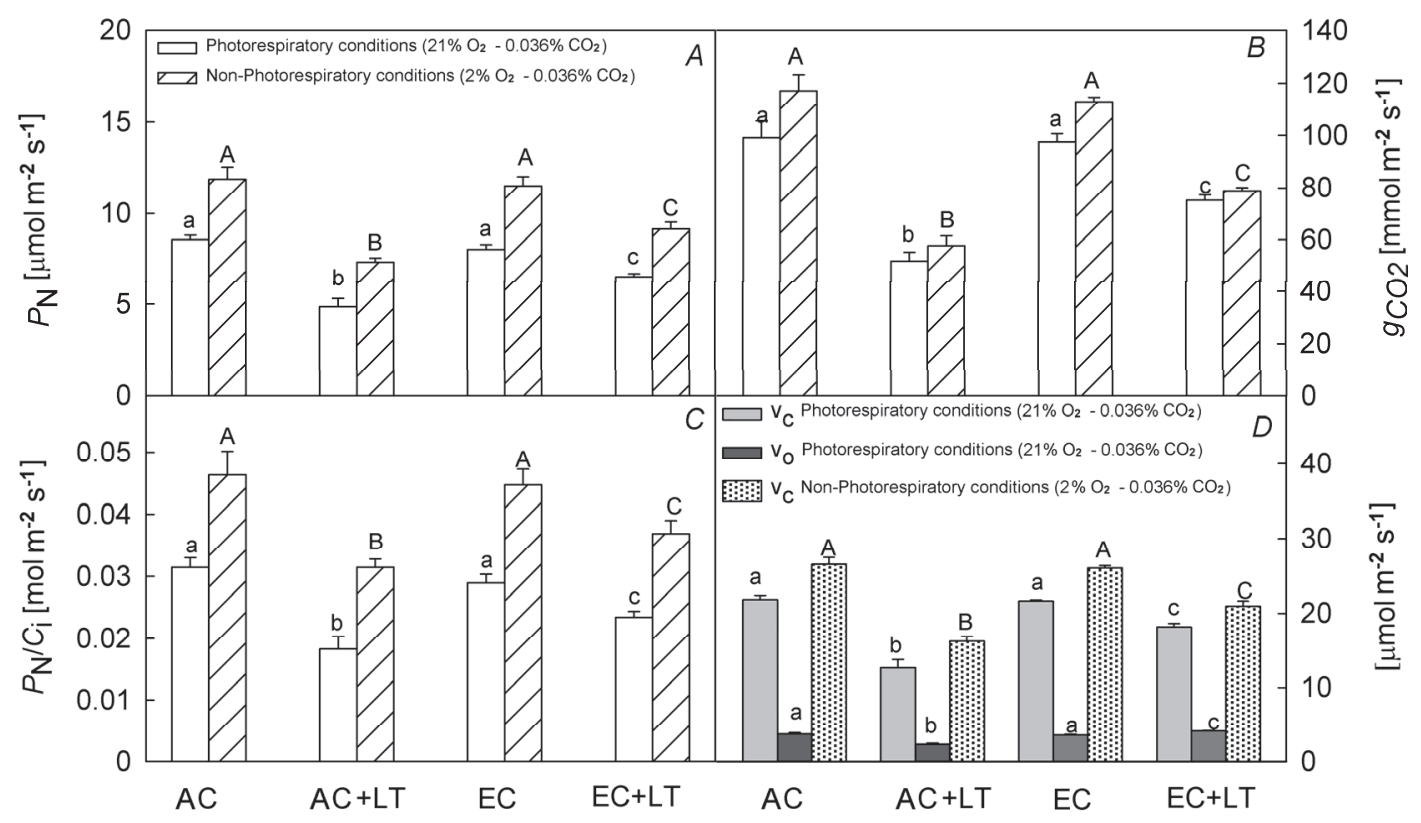

Fig. 2. (A) Net photosynthetic rate $\left(P_{\mathrm{N}}\right),(B) \mathrm{CO}_{2}$ stomatal conductance, $\left(g_{\mathrm{s}}\right),(C)$ apparent Rubisco efficiency $\left(P_{\mathrm{N}} / C_{\mathrm{i}}\right)$, and $(D)$ carboxylation $\left(V_{\mathrm{c}}\right)$ and oxygenation $\left(V_{\mathrm{o}}\right)$ rates of Rubisco, measured before and after different treatments under photorespiratory $(21 \%$ $\mathrm{O}_{2}$ and $\left.0.036 \% \mathrm{CO}_{2}\right)$ and nonphotorespiratory $\left(2 \% \mathrm{O}_{2}\right.$ and $\left.0.036 \% \mathrm{CO}_{2}\right)$ conditions. Values are means $\pm \mathrm{SE}(n=6) . \mathrm{AC}-\mathrm{ambient}\left[\mathrm{CO}_{2}\right]$; $\mathrm{AC}+\mathrm{LT}$ - ambient $\left[\mathrm{CO}_{2}\right]$ and low temperature; $\mathrm{EC}$ - elevated $\left[\mathrm{CO}_{2}\right] ; \mathrm{EC}+\mathrm{LT}$ - elevated $\left[\mathrm{CO}_{2}\right]$ and low temperature. Small and capital letters indicate statistically significant differences between treatments under photorespiratory and nonphotorespiratory conditions. 


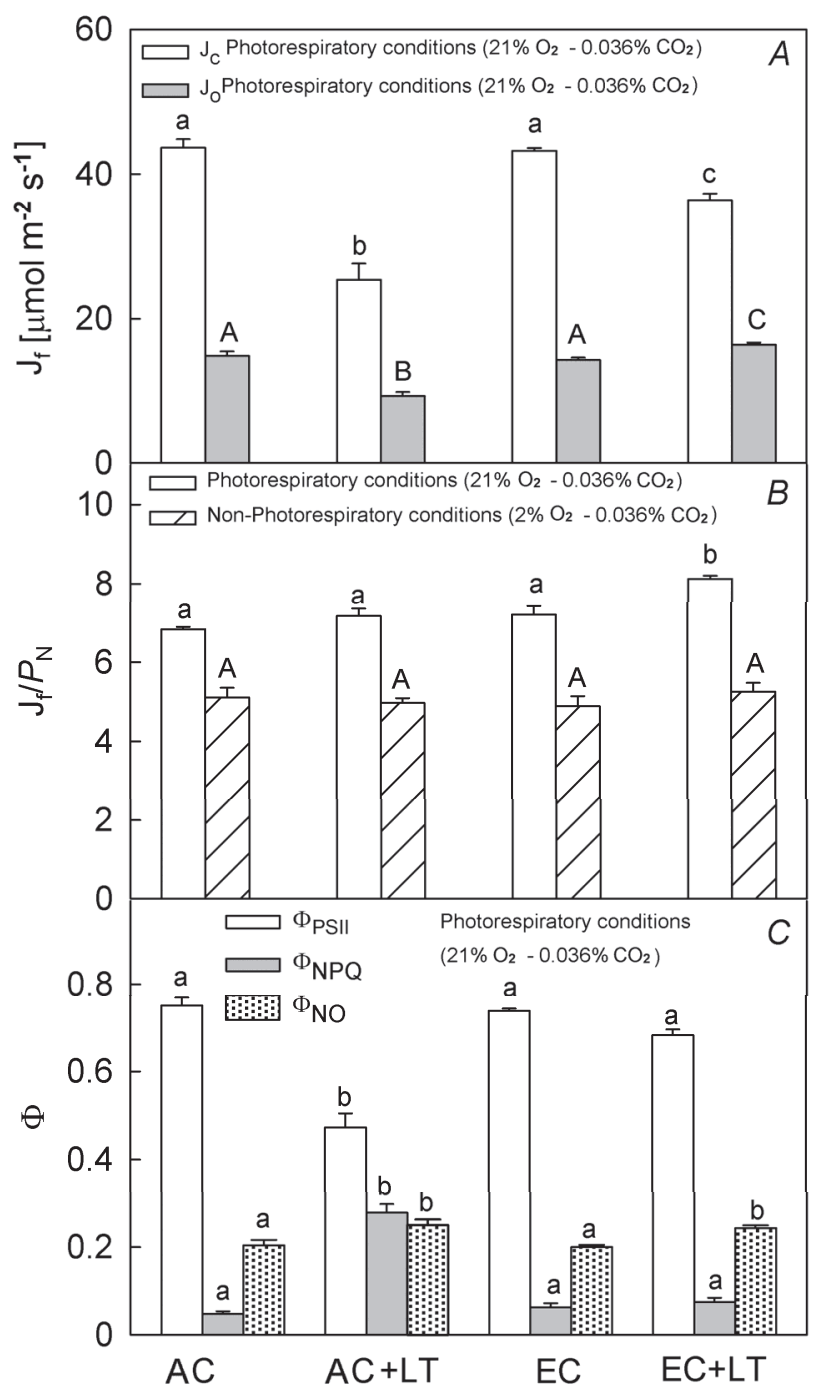

Fig. 3: $(A)$ Fraction of electron transport $\left(J_{\mathrm{f}}\right)$ used in $\mathrm{CO}_{2}$ assimilation $\left(J_{\mathrm{c}}\right)$ and in photorespiration $\left(J_{\mathrm{o}}\right),(B)$ ratio of electron transport and net photosynthesis $\left(J_{\mathrm{f}} / P_{\mathrm{N}}\right),(C)$ effective quantum yield of PSII photochemistry (ФPSII), yield of regulated energy dissipation $\left(\Phi_{\mathrm{NPQ}}\right)$, and nonregulated energy dissipation $\left(\Phi_{\mathrm{NO}}\right)$, measured before and after different treatments under photorespiratory $\left(21 \% \mathrm{O}_{2}\right.$ and $\left.0.036 \% \mathrm{CO}_{2}\right)$ and nonphotorespiratory $\left(2 \% \mathrm{O}_{2}\right.$ and $\left.0.036 \% \mathrm{CO}_{2}\right)$ conditions. Values are means $\pm \mathrm{SE}$ $(n=6)$. AC - ambient $\left[\mathrm{CO}_{2}\right] ; \mathrm{AC}+\mathrm{LT}-$ ambient $\left[\mathrm{CO}_{2}\right]$ and low temperature; $\mathrm{EC}$ - elevated $\left[\mathrm{CO}_{2}\right] ; \mathrm{EC}+\mathrm{LT}$ - elevated $\left[\mathrm{CO}_{2}\right]$ and low temperature. Small and capital letters indicate statistically significant differences between treatments under photorespiratory and nonphotorespiratory conditions.

water relations during the chilling event and mitigate the photosynthetic depression as well as chilling damages (Boese et al. 1997, Drake et al. 1997).

The decline of $P_{\mathrm{N}}$ and $P_{\mathrm{N}} / C_{\mathrm{i}}$ ratio, observed in $\mathrm{AC}+\mathrm{LT}$ and $\mathrm{EC}+\mathrm{LT}$ plants, suggests that Rubisco represents a critical factor in photosynthesis recovery of $B$. vulgaris plants. More specifically, the slow recovery of $P_{\mathrm{N}}$, after returning to prechilling conditions, could be attributed not only to the decrease of stomatal conductance but also to the loss of Rubisco activity due to the reduction of its content. It is noteworthy that the harmful effects of low temperature on Rubisco activity are often associated with changes in its concentration (Galmés et al. 2013). Our data indicate that the exposure of plants to elevated $\mathrm{CO}_{2}$, alone or in combination with low temperature, determined differences in Rubisco expression that might have affected its activity during recovery. Consistent with this hypothesis, we observed a decrease of photosynthesis in $\mathrm{AC}+\mathrm{LT}$ plants together with an important reduction of Rubisco expression level.

Even if Rubisco is a very abundant and quite stable protein, its synthesis is limited under low temperatures (Meza-Basso et al. 1986). Thus, the high drop (56\%) of Rubisco content observed under cold may be due to the slow capability of this enzyme to recover after a chilling event. More specifically, so drastic reduction observed in LT plants suggests that the Rubisco degradation during chilling exceeded its synthesis. This unbalance might negatively affect the carboxylase/oxygenase activity, as confirmed by the significant decrease of $V_{\mathrm{c}}$ and $V_{\mathrm{o}}$.

The reduction of carboxylase activity is also accompanied by the decline of the oxygenase activity (Allen and Ort 2001). In our experimental conditions, the combination chilling/elevated $\mathrm{CO}_{2}$ led to the reduction of carboxylation rate $\left(V_{\mathrm{c}}\right)$, likely due to an impairment of $\mathrm{CO}_{2}$ assimilation, and to the increase of oxygenation rate $\left(V_{\mathrm{o}}\right)$. We hypothesise that the substantial decrease $(56 \%)$ of Rubisco amount in AC+LT leaves, compared with control, was the result of an accelerated degradation of the protein induced by cold. On the other hand, the small reduction (9\%) found in EC+LT leaves could be ascribed to a stimulatory effect of elevated $\mathrm{CO}_{2}$ on Rubisco synthesis. It is noteworthy that short-term exposure to elevated $\mathrm{CO}_{2}$ leads to an increase of leaf-level photosynthesis due to enhanced activity of Rubisco (Moore et al. 1999, Urbonavičiūtè et al. 2006). In our experiment, the highest Rubisco amount was found in EC leaves, suggesting the hypothesis of a direct stimulation of elevated $\mathrm{CO}_{2}$ on enzyme activity (Seneweera et al. 2011, Jiang et al. 2012, Rai et al. 2016). In our experimental context, the elevated $\mathrm{CO}_{2}$ concentration in combination with low temperature exerted a mitigating effect on reduction of Rubisco content induced by chilling. This allowed EC+LT leaves to maintain higher photosynthetic rates and reduce the adverse effect of low temperature on Rubisco oxygenase activity, upon return to prechilling conditions. The elevated $\mathrm{CO}_{2}$ concentrations increased the Rubisco content, but it resulted in a significantly higher $P_{\mathrm{N}}$ only under saturating light levels, as shown by light-response curves, being photosynthesis limited by ribulose-1,5bisphosphate $(\mathrm{RuBP})$ regeneration at low irradiance levels. Our data demonstrate that the effect of elevated $\mathrm{CO}_{2}$ concentrations on Rubisco protein content is evident and determines significant consequences not only after longterm growth but also after a few hours of exposure of plants to elevated $\mathrm{CO}_{2}$ (Cheng et al. 1998). 

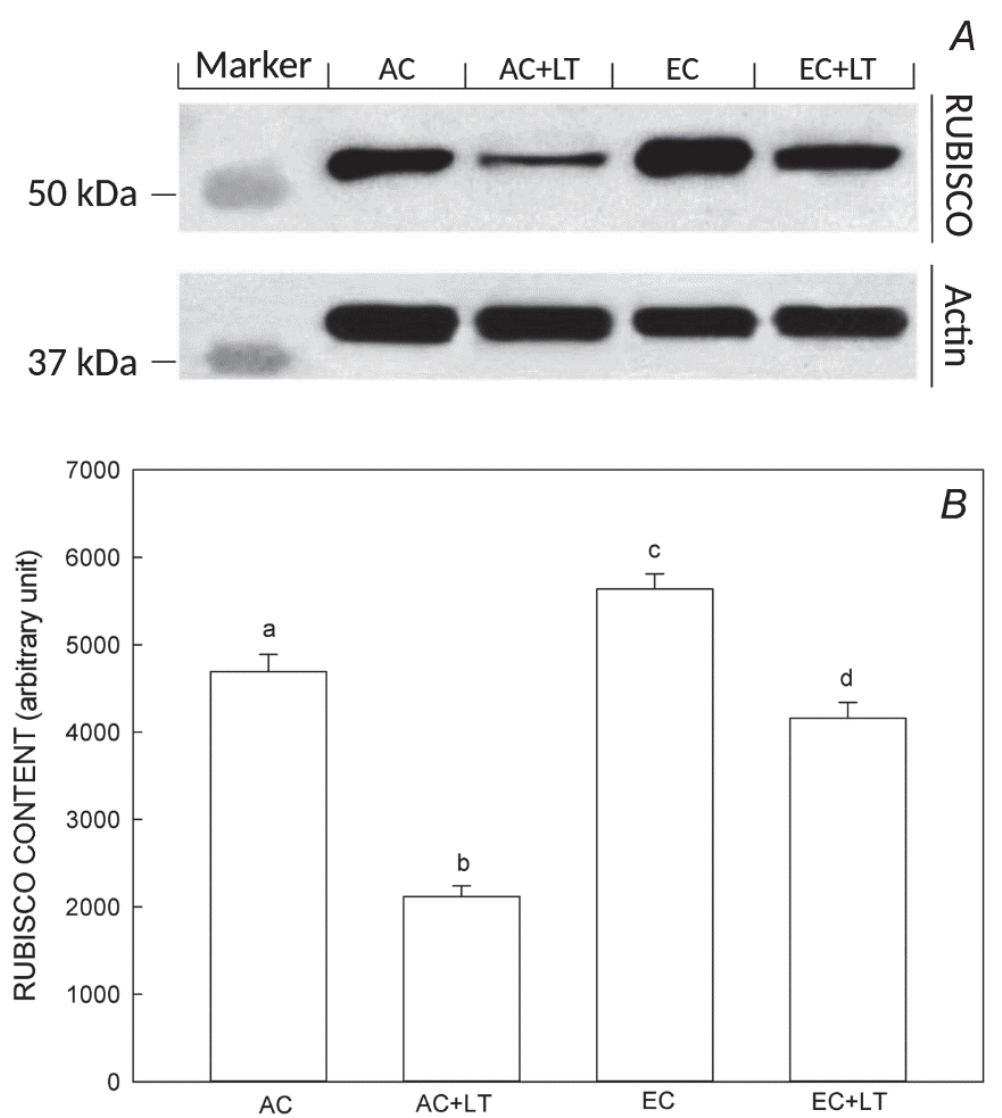

Fig. 4: (A) Rubisco expression (B) and content measured at the end of each treatment. Rubisco protein content in control and treated plants was determined by immunoblotting with protein-specific primary antibody. Actin was used as loading control. The bar diagrams represent pixel volumes of Rubisco bands normalised to the appropriate actin band. Values are means $\pm \mathrm{SE}(n=6)$. AC - ambient $\left[\mathrm{CO}_{2}\right]$; $\mathrm{AC}+\mathrm{LT}-$ ambient $\left[\mathrm{CO}_{2}\right]$ and low temperature; $\mathrm{EC}-$ elevated $\left[\mathrm{CO}_{2}\right] ; \mathrm{EC}+\mathrm{LT}$ - elevated $\left[\mathrm{CO}_{2}\right]$ and low temperature. Different letters indicate statistically significant differences between treatments at $21 \% \mathrm{O}_{2}$.
Effects of different treatments on photochemistry and light energy partitioning: When $\mathrm{CO}_{2}$ assimilation is limited by chilling, the excess of absorbed light must be dissipated to prevent or minimise the formation of reactive oxygen species, dangerous for the photosynthetic membranes. The exposure to chilling caused an instantaneous decline of PSII efficiency in both $\mathrm{AC}+\mathrm{LT}$ and $\mathrm{EC}+\mathrm{LT}$ plants accompanied by the reduction of $\mathrm{F}_{\mathrm{v}} / \mathrm{F}_{\mathrm{m}}$ ratio; this was less pronounced in $\mathrm{EC}+\mathrm{LT}$ plants.

Harmful conditions for photosynthetic apparatus may also persist after chilling, because of a delayed recovery of photosynthesis, enhancing the risks of photoinhibition or photooxidative damages (Melkonian et al. 2004). In our experiment, the recovery of $F_{v} / F_{m}, F_{0}$, and $F_{m}$ within $14 \mathrm{~h}$ from chilling treatments indicated a reversible inactivation of PSII reaction centres in both $\mathrm{AC}+\mathrm{LT}$ and $\mathrm{EC}+\mathrm{LT}$ plants.

The capability of photosynthetic apparatus to recover after sudden temperature drops is associated to the activation of photoprotective pathways during recovery, ensuring the maintenance of plant productivity within certain limits. It may be crucial for many crop species, as chard, cultivated in Mediterranean areas, where short chilling episodes are typical during winter.

Even if both $\mathrm{AC}+\mathrm{LT}$ and $\mathrm{EC}+\mathrm{LT}$ plants showed the full recovery of photochemistry after $14 \mathrm{~h}$ from chilling, our results showed a significant chilling-induced reduction of photosynthesis in $\mathrm{AC}+\mathrm{LT}$ compared to $\mathrm{EC}+\mathrm{LT}$ plants, evidencing the positive effect of elevated $\mathrm{CO}_{2}$ in mitigating chilling stress.

The different behaviour could be due to the different utilisation of the absorbed light in photochemistry. In $\mathrm{AC}+\mathrm{LT}$ plants, the partitioning of reductive power between photosynthesis and alternative sinks consuming electrons, estimated by $J_{\mathrm{f}} / P_{\mathrm{N}}$ ratio, did not vary compared to prechilling conditions (AC), indicating that the electron transport rate $\left(J_{\mathrm{f}}\right)$ was down-regulated by carbon metabolism. Our results are in contrast with data reported by other authors (Melkonian et al. 2004, Zhou et al. 2004) who found a higher electron flow to alternative photochemical sinks other than $\mathrm{CO}_{2}$ fixation after returning to prechilling conditions.

Conversely to $\mathrm{AC}+\mathrm{LT}$, in $\mathrm{EC}+\mathrm{LT}$ plants, the $J_{\mathrm{f}} / P_{\mathrm{N}}$ ratio was higher compared to prechilling conditions, indicating a significant proportion of electron flew to processes other than $\mathrm{CO}_{2}$ assimilation. The parallel increase of $J_{\mathrm{o}}$ in these plants, suggests that, among different sinks, a part of electron flow was directed to photorespiration.

The different behaviour between $\mathrm{AC}+\mathrm{LT}$ and $\mathrm{EC}+\mathrm{LT}$ plants was evident also from the analysis of the partitioning of absorbed light within PSII. As compared to the prechilling conditions, the exposure to low temperatures determined, in $\mathrm{AC}+\mathrm{LT}$ plants, a reduction of light energy used in photochemistry ( $\Phi_{\mathrm{PSII}}$ ), according to the $P_{\mathrm{N}}$ decrease. Contextually, the fraction of the regulated $\Delta \mathrm{pH}-$ and xanthophyll-dependent thermal dissipation, $\Phi_{\mathrm{NPQ}}$, increased by about $80 \%$ compared to prechilling 
conditions, highlighting the importance of this pathway of thermal dissipation in consuming the excess of excitation energy when photochemistry and photosynthesis are reduced. However, $\Phi_{\mathrm{NPQ}}$ was not sufficient to prevent the drastic reduction of maximal photochemical efficiency $\left(\mathrm{F}_{\mathrm{v}} / \mathrm{F}_{\mathrm{m}}\right)$ observed in $\mathrm{AC}+\mathrm{LT}$ leaves. In $\mathrm{EC}+\mathrm{LT}$ plants, even if the contribution of $\Phi_{\mathrm{NPQ}}$ was negligible compared to that occurred before the chilling conditions, only a slight reduction of $\mathrm{F}_{\mathrm{v}} / \mathrm{F}_{\mathrm{m}}$ was observed. It may be hypothesised that in these plants, the increase of electron flow to $\mathrm{O}_{2}$ successfully contributed to dissipate the excess of light energy to photosystems.

Conversely to $\Phi_{\mathrm{NPQ}}$, the nonregulated energy dissipation in PSII $\left(\Phi_{\mathrm{NO}}\right)$ similarly increased in the two plant groups compared with control, indicating that a fraction of absorbed light was diverted to nonregulated energy conversion processes, favouring the production of reactive

\section{References}

Alam B., Jacob J.: Overproduction of photosynthetic electrons is associated with chilling injury in green leaves. - Photosynthetica 40: 91-95, 2002.

Allen D.J., Ort D.R.: Impacts of chilling temperatures on photosynthesis in warm climate plants. - Trends Plant Sci. 6: 36-42, 2001.

Ainsworth E.A., Rogers A.: The response of photosynthesis and stomatal conductance to rising $\mathrm{CO}_{2}$ : mechanisms and environmental interactions. - Plant Cell Environ. 30: 258-270, 2007.

Arena C., Figlioli F., Sorrentino M.C. et al.: Ultrastructural, protein and photosynthetic alterations induced by $\mathrm{Pb}$ and $\mathrm{Cd}$ in Cynara cardunculus L., and its potential for phytoremediation. Ecotoxicol. Environ. Safe. 145: 83-89, 2017.

Bertrand A., Prevost D., Bigras F.J., Castonguay Y.: Elevated atmospheric $\mathrm{CO}_{2}$ and strain of rhizobium after freezing tolerance and cold-induced molecular changes in Alfalfa. (Medicago sativa). - Ann. Bot.-London 99: 275-284. 2007.

Bigras F.J., Bertrand A.: Responses of Picea mariana to elevated $\mathrm{CO}_{2}$ concentration during growth, cold hardening and dehardening phenology, cold tolerance, photosynthesis and growth. - Tree Physiol. 26: 875-888, 2006.

Bilger W., Björkman O.: Role of xanthophyll cycle in photoprotection elucidated by measurements of light-induced absorbance changes, fluorescence and photosynthesis in Hedera canariensis. - Photosynth. Res. 25: 173-185, 1990.

Boese S.R., Wolfe D.A., Melkonian J.J.: Elevated $\mathrm{CO}_{2}$ mitigates chilling-induced water stress and photosynthetic reduction during chilling. - Plant Cell Environ. 20: 625-632, 1997.

Cheng S-H., Moore B.D., Seemann J.R.: Effects of short- and longterm elevated $\mathrm{CO}_{2}$ on the expression of Ribulose-1,5bisphosphate carboxylase/oxygenase genes and carbohydrate accumulation in leaves of Arabidopsis thaliana (L.) Heynh. Plant Physiol. 116: 715-723, 1998.

Dahal K., Knowles V., Plaxton W.C., Hüner N.P.A.: Enhancement of photosynthetic performance, water use efficiency and grain yield during long-term growth under elevated $\mathrm{CO}_{2}$ in wheat and rye is growth temperature and cultivar depend. - Environ. Exp. Bot. 106: 207-220, 2014.

Drake B.G., Gonzales-Meler M.A., Long S.P.: More efficient plants: a consequence of rising atmospheric $\mathrm{CO}_{2}$ ? - Annu. Rev. Plant Phys. 48: 609-639, 1997. oxygen species (ROS) (Wang et al. 2009).

Nevertheless, even if the potential risk linked to the ROS production is similar for $\mathrm{AC}+\mathrm{LT}$ and $\mathrm{EC}+\mathrm{LT}$ plants, the dissipative processes activated by elevated $\mathrm{CO}_{2}$ under low temperatures are more effective in limiting ROS action and are able to guarantee a higher photosynthesis and maximal photochemical efficiency in EC+LT plants.

In conclusion, the simultaneous short exposures of plants to low temperature and elevated $\mathrm{CO}_{2}$ increased photorespiration upon to return to the prechilling conditions. Conversely, the exposure to low temperatures actively promoted the regulated thermal dissipation processes. These two dissipation mechanisms were not equally effective in PSII photoprotection as confirmed by the highest reduction of photosynthesis and maximal photochemical efficiency in $\mathrm{AC}+\mathrm{LT}$ compared to $\mathrm{EC}+\mathrm{LT}$ plants after chilling events.

Duarte B., Santos D., Silva H. et al:: Photochemical and biophysical feedbacks of $\mathrm{C}_{3}$ and $\mathrm{C}_{4}$ Mediterranean halophytes to atmospheric $\mathrm{CO}_{2}$ enrichment confirmed by their stable isotope signatures. - Plant Physiol. Bioch. 80: 10-22, 2014.

Epron D., Godard D., Cornic G., Genty B.: Limitation of net $\mathrm{CO}_{2}$ assimilation rate by internal resistances to $\mathrm{CO}_{2}$ transfer in the leaves of two tree species (Fagus sylvatica L. and Castanea sativa Mill.). - Plant Cell Environ. 18: 43-51, 1995.

Flexas J., Escalona J.M., Medrano H.: Down-regulation of photosynthesis by drought under field conditions in Grapevines leaves. - Aust. J. Plant Physiol. 25: 893-900, 1998.

Fryer M.J., Andrews J.R., Oxborough K. et al:: Relationship between $\mathrm{CO}_{2}$ assimilation, photosynthetic electron transport, and active $\mathrm{O}_{2}$ metabolism in leaves of maize in the field during periods of low temperature. - Plant Physiol. 116: 571-580, 1998.

Galmés J., Aranjuelo I., Medrano H., Flexas J.: Variation in Rubisco content and activity under variable climatic factors. Photosynth. Res. 117: 73-90, 2013.

Genty B., Briantais J., Baker N.R.: The relationship between quantum yield of photosynthetic electron transport and quenching of chlorophyll fluorescence. - Biochim. Biophys. Acta 990: 87-92, 1989 .

Govindachary S., Bukhov N.G., Joly D., Carpentier R.: Photosystem II inhibition by moderate light under low temperature in intact leaves of chilling-sensitive and tolerant plants. - Physiol. Plantarum 121: 322-333, 2004.

Gutiérrez D., Gutiérrez E., Pérez P. et al.: Acclimation to future atmospheric $\mathrm{CO}_{2}$ levels increases photochemical efficiency and mitigates photochemistry inhibition by warm temperatures in wheat under field chambers. - Physiol. Plantarum 137: 86-100, 2009.

Hamilton E.W., Heckathorn S.A., Joshi P. et al.: Interactive effects of elevated $\mathrm{CO}_{2}$ and growth temperature on the tolerance of photosynthesis to acute heat stress in $\mathrm{C} 3$ and $\mathrm{C} 4$ species. - J. Integr. Plant Biol. 50: 1375-1387, 2008.

Huang W., Zhang S.B., Cao K.F.: The different effects of chilling stress under moderate light intensity on photosystem II compared with photosystem I and subsequent recovery in tropical tree species. - Photosynth. Res. 103: 175-182, 2010.

Huner N.P.A., Öquist G., Hurry V.M. et al:: Photosynthesis, photoinhibition and low temperature acclimation in cold tolerant 
plants. - Photosynth. Res. 37: 19-39, 1993.

Janská A. Maršík P., Zelenková S., Ovesná J.: Cold stress and acclimation - what is important for metabolic adjustment? Plant Biol. 12: 395-405, 2010.

Jiang Y.-P., Cheng F., Zhou Y.-H. et al.: Interactive effects of $\mathrm{CO}_{2}$ enrichment and brassinosteroid on $\mathrm{CO}_{2}$ assimilation and photosynthetic electron transport in Cucumis sativus. - Environ. Exp. Bot. 75: 98-106, 2012.

Krall J.P., Edwards G.E.: Relationship between Photosystem II activity and $\mathrm{CO}_{2}$ fixation in leaves. - Physiol. Plantarum 86: 180187, 1992.

Kramer D.M., Johnson G., Kiirats O., Edwards G.E.: New fluorescence parameters for the determination of $\mathrm{Q}_{\mathrm{A}}$ redox state and excitation energy fluxes. - Photosynth. Res. 79: 209-218, 2004.

Laing W.A., Greer D.H., Campbell B.C.: Strong responses of growth and photosynthesis of five $\mathrm{C}_{3}$ pasture species to elevated $\mathrm{CO}_{2}$ at low temperatures. - Funct. Plant Biol. 29: 1089-1096, 2002.

Leipner J., Basilidès A., Stamp P., Fracheboud Y.: Hardly increased oxidative stress after exposure to low temperature in chilling acclimated and non-acclimated maize leaves. - Plant. Biol. 2: 243-251, 2000.

Loveys B.R., Egerton J.J.G., Ball M.C.: Higher daytime leaf temperatures contribute to lower freeze tolerance under elevated CO 2 . - Plant Cell Environ. 29: 1077-1086, 2006.

Martin B., Ort D.R., Boyer J.S.: Impairment of photosynthesis by chilling-temperatures in tomato. - Plant Physiol. 68: 329-334, 1981.

Martin M., Gavazov K., Körner C. et al.: Reduced early growing season freezing resistence in alpine treeline plants under elevated atmospheric $\mathrm{CO}_{2}$ - - Glob. Change Biol. 16: 1057-1070, 2010.

Medrano H., Bota J., Abadía A. et al.: Effects of drought on lightenergy dissipation mechanisms in high-light-acclimated, fieldgrown grapevines. - Funct. Plant Biol. 29: 1197-1207, 2002.

Melkonian J., Owens T.G., Wolfe D.W.: Gas exchange and coregulation of photochemical and non-photochemical quenching in bean during chilling at ambient and elevated carbon dioxide. Photosynth. Res. 79: 71-82, 2004.

Meza-Basso L., Alberdi M., Raynal M. et al.: Changes in protein synthesis in rapeseed (Brassica napus) seedlings during a low temperature treatment. - Plant Physiol. 82: 733-738, 1986.

Moore B.D, Cheng S.H., Sims D, Seemann J.R.: The biochemical and molecular basis for photosynthetic acclimation to elevated atmospheric $\mathrm{CO}_{2}$. - Plant Cell Environ. 22: 567-582, 1999.

$\mathrm{Qu}$ M.N., Bunce J.A., Shi Z.S.: Does elevated $\mathrm{CO}_{2}$ protect photosynthesis from damage by high temperature via modifying leaf water status in maize seedlings? - Photosynthetica 52: 211216, 2014.

Rai P., Chaturvedi A.K., Viswanathan D.S.C., Pal M.: Elevated $\mathrm{CO}_{2}$ enhances carbohydrate assimilation at flowering stage and seed yield in chickpea (Cicer arietinum). - Ind. J. Plant Physiol. 21: 114-121, 2016.
Rapacz M., Wolanin B., Hura K., Tyrka M.: The effects of cold acclimation on photosynthetic apparatus and the expression of COR14b in four genotypes of barley (Hordeum vulgare) contrasting in their tolerance to freezing and high-light treatment in cold conditions. - Ann. Bot.-London 101: 689-699, 2008.

Sanz-Sáez Á., Erice G., Aranjuelo I. et al.: Photosynthetic and molecular markers of $\mathrm{CO}_{2}$-mediated photosynthetic down regulation in nodulated alfalfa. - J. Integr. Plant Biol. 55: 721734, 2013.

Seneweera S., Makino A., Hirotsu N., Norton S.Y.: New insight into photosynthetic acclimation to elevated $\mathrm{CO}_{2}$ : the role of leaf nitrogen and ribulose-1,5-bisphosphate carboxylase/oxygenase content in rice leaves. - Environ. Exp. Bot. 71: 128-136, 2011.

Urban O., Hrstka M., Zitová M. et al.: Effect of season, needle age and elevated $\mathrm{CO}_{2}$ concentration on photosynthesis and Rubisco acclimation in Picea abies. - Plant Physiol. Bioch. 58: 135-141, 2012.

Urbonavičiūtè A., Samuolienė G., Sakalauskaitė J. et al.: The effect of elevated $\mathrm{CO}_{2}$ concentrations on leaf carbohydrate, chlorophyll contents and photosynthesis in radish. - Pol. J. Environ. Stud. 15: 921-925, 2006.

Venema J.H., Posthumus F., de Vries M., van Hasselt P.R.: Differential response of domestic and wild Lycopersicon species to chilling under low light: growth, carbohydrate content, photosynthesis and the xanthophyll cycle. - Physiol. Plantarum 105: 81-88, 1999.

Venema J.H., Villerius L., van Hasselt P.R.: Effects of acclimation to suboptimal temperature on chilling-induced photodamage: comparison between a domestic and a high-altitude wild Lycopersicon species. - Plant Sci. 152: 153-163, 2000.

von Caemmerer S., Farquhar G.D.: Some relationship between the biochemistry of photosynthesis and the gas exchange of leaves. - Planta 153: 376-387, 1981.

von Caemmerer S.: Biochemical Models of Leaf Photosynthesis. Pp. 165. CSIRO Publishing, Collingwood 2000.

Wang L.J., Loescher W., Duan W. et al.: Heat acclimation induced acquired heat tolerance and cross adaptation in different grape cultivars: relationships to photosynthetic energy partitioning. Funct. Plant Biol. 36: 516-526, 2009.

Zheng C., Chen Z., Xia J. et al.: Chilling acclimation provides immunity to stress by altering regulatory networks and inducing genes with protective functions in cassava. - BMC Plant Biol. 14: 207, 2014.

Zhou Y.H., Yo O.J., Huang L.R., Nogués S.: The relationship between $\mathrm{CO}_{2}$ assimilation, photosynthetic electron transport and water-water cycle in chill-exposed cucumber leaves under low light and subsequent recovery. - Plant Cell Environ. 27: 15031514, 2004.

Ziska L.H.: Growth temperature can alter the temperature dependent stimulation of photosynthesis by elevated carbon dioxide in Albutilon theophrasti. - Physiol. Plantarum 111: 322328, 2001. 